\title{
PENGARUH LAMA PERENDAMAN MENGGUNAKAN CUKA SAGUER TERHADAP PENINGKATAN KUALITAS FISIK DAGING ENTOK (Chairina moschata)
}

\author{
Erlita N. Jengel ", E.H.B. Sondakh, F.S. Ratulangi, C.K.M. Palar \\ Fakultas Peternakan Universitas Sam Ratulangi Manado, 95115
}

\begin{abstract}
ABSTRAK
Penelitian ini bertujuan untuk menentukan kualitas sifat fisik daging entok setelah direndam dengan cuka saguer. Cuka saguer yang digunakan untuk perendaman daging dalam penelitian ini adalah hasil fermentasi dari cairan pohon enau. Daging yang digunakan untuk direndam adalah daging entok yang diambil bagian dada. Percobaan ini menggunakan rancangan acak lengkap dengan lima perlakuan yang terdiri dari perlakuan R0 daging entok tanpa direndam, $\mathrm{R} 1$ daging entok yang direndam dengan cuka saguer selama 20 menit, R2 daging entok yang direndam dengan cuka saguer selama 40 menit, R3 daging entok yang direndam dengan cuka saguer selama 60 menit, dan R4 daging entok yang direndam dengan cuka saguer selama 80 menit. Setiap perlakuan dilakukan empat kali ulangan. Apabila terdapat perbedaan yang nyata dalam analisis varian maka pembanding rata-rata dilakukan dengan menggunakan uji DMRT. Hasil penelitian menunjukkan bahwa perendaman dengan cuka saguer pada daging entok memberikan pengaruh yang signifikan terhadap $\mathrm{pH}$ dan daya mengikat air, sedangkan tekstur daging tidak signifikan. Kesimpulannya adalah perendaman selama 20 menit dengan cuka saguer dapat digunakan untuk merendam daging entok karena secara kualitas dapat mempertahankan tekstur daging dan meningkatkan daya ikat air daging pada kondisi $\mathrm{pH}$ daging yang normal.
\end{abstract}

Kata kunci: daging entok, cuka saguer, kualitas fisik daging

\footnotetext{
*Korespondensi (corresponding author):

Email: ningsih_erlita@yahoo.co.id
}

\begin{abstract}
THE EFFECT OF MARINATING TIME USING CUKA SAGUER ON PHYSICAL QUALITY INCREASING OF ENTOK MEAT (Chairina Moschata). This study aims to determine of physical quality of entok meat after marinating with cuka saguer. Cuka saguer using to soak meat in this research was obtained from fermentated yield of fluid from enau tree. The marinated meat in this research was entok meat. This experiment was arranged in a completely randomized design consisted of five treatments as followed $\mathrm{R} 0$ entok meat was without marinated, R1 entok meat was marinated for 20 minutes, R2 entok meat was marinated for 40 minutes, R3 entok meat was marinated for 60 minutes, $\mathrm{R} 4$ entok meat was marinated for 80 minutes and each treatment was conducted four times replication. If occur significant in analysis of variance so the average comparing was followed by DMRT test. The result showed The marinated entok meat using cuka saguer was significantly on $\mathrm{pH}$ and water holding capacity (WHC), while texture of meat no significant. In conclusion, the soaking time for 20 minutes with cuka saguer can be used to soak entok meat because able to maintain texture of meat and to increase WHC at the condition of $\mathrm{pH}$ normal.
\end{abstract}

Keywords: entok meat, cuka saguer, physical quality of meat 


\section{PENDAHULUAN}

Daging itik merupakan bahan pangan asal ternak yang semakin populer di Indonesia. Pengembangan ternak itik pun terus dilakukan, baik untuk tipe petelur maupun pedaging. Terdapat beragam jenis itik yang telah dikembangkan diantaranya Itik Ratu yang dikenal memiliki produksi telur yang tinggi dan Itik Raja yang dipelihara sebagai itik pedaging. masyarakat Sulawesi Utara yang pada umumnya beternak secara ekstensif (tradisional) banyak memelihara jenis Itik Serati atau dikenal sebagai Mentok; Entok atau Bebek Manila. Daging entok (Cairina moschata) oleh masyarakat biasanya diolah menjadi masakan berbumbu khas Minahasa seperti bumbu RW. Namun dalam pengolahan daging Entok, sering dilakukan perlakuan khusus terutama untuk menghilangkan bau amis dan tekstur daging yang agak keras. Penambahan zat tertentu (aditif) pada suatu bahan pangan sudah sering dilakukan dalam meningkatkan kualitas fisik maupun kimia dari produk pangan itu sendiri. Terdapat beberapa aditif yang banyak digunakan dikalangan masyarakat untuk memperbaiki produk pangan, namun penggunaan tersebut terkadang tidak terkontrol yang mengakibatkan penurunan kualitas produk. Itulah sebabnya diperlukan kehati-hatian dalam menggunakan aditif.
Beberapa penelitian menunjukan penggunaan asam pada daging sudah sering dilakukan seperti halnya menggunakan jeruk dan asam cuka. Namum penelitian-penelitian tersebut hanya sebatas pengawetan, sementara penggunaan cuka terhadap kualitas sifat fisik daging masih belum banyak terpublikasi. Penggunaan dengan menggunakan asam yang tidak terkontrol dapat mengakibatkan penurunan kualitas produk.

Proses perendaman dapat meningkatkan efek positif pada daging dan resiko kehilangan air pada saat pengolahan akan lebih sedikit dan mempertahankan kualitas daging juga dapat dilakukan dengan penggunaan bahan-bahan tambahan yang aman bagi produk daging itu sendiri. Salah satunya dengan menggunakan bahan pengawet alami yang mudah didapat dan tidak mengganggu kesehatan, bahan pengawet tersebut diantaranya cuka saguer yang didapat dari pohon aren (Arena pinata).

Penggunaan cuka saguer jarang dilakukan kondisi ini memberikan peluang untuk diteliti produk cuka saguer tersebut sebagai penentu terhadap kualitas daging. Cuka saguer bahan yang berasal dari nira aren diduga dapat digunakan sebagai aditif dalam produk pangan terhadap peningkatan kualitas daging entok. 


\section{MATERI DAN METODE PENELITIAN}

Penelitian ini dilaksanakan di Laboratorium Teknologi Hasil Ternak Fakultas Peternakan Universitas Sam Ratulangi Manado dan di Laboratorium Akademi Gizi Manado. Bahan yang digunakan dalam penelitian ini yaitu daging entok bagian dada. Diambil dari beberapa ekor ternak yang berumur enam bulan. Cuka saguer yang digunakan dalam penelitian ini adalah hasil fermentasi yang berasal dari cairan pohon enau dari perkebunan Desa Tateli Kabupaten Minahasa Utara. Peralatan yang digunakan adalah timbangan, alat penyaring, pisau, labeling, tissue, penggaris, wadah, stopwatch, oven, desikator, pingset, penetrometer, jangka, kertas whatman 41 , kertas obat, almonium foil, alat tulis menulis dan peralatan penunjang lainnya.

\section{Metode Penelitian}

Cairan (saguer) yang berasal dari pohon enau diambil sebanyak 4 liter kemudian di simpan selama dua minggu untuk menghasilkan cuka saguer. Dilakukan pengujian kadar kosentrasi asam asetat dalam cuka saguer. Cuka saguer disaring untuk memisahkan kotoran yang ada, selanjutnya bahan ini digunakan sebagai percobaan untuk perendaman daging entok. Disiapkan dua puluh wadah gelas, enam belas wadah diisi dengan cuka saguer sebanyak $50 \mathrm{ml}$. dan empat wadah dibiarkan kosong. Setiap wadah dimasukkan daging entok sebanyak 25 gram untuk dilakukan percobaan. Perlakuan yang diterapkan dalam penelitian ini adalah perlakuan perendaman dengan cuka saguer yang terdiri dari 5 perlakuan dan 4 kali ulangan dengan formulasi percobaan sebagai berikut : $\mathrm{R} 0=$ Daging entok tidak direndam dengan cuka saguer; R1 = Daging entok direndam dengan cuka saguer selama 20 menit; R2 = Daging entok direndam dengan cuka seguer selama 40 menit; R3 = Daging entok direndam dengan cuka saguer selama 60 menit; $\mathrm{R} 4=$ Daging entok direndam dengan cuka saguer selama 80 menit.

Variabel yang diamati pada penelitian ini adalah $\mathrm{pH}$ (Nurwantoro et al., 2012), daya mengikat air (Swatland, 1984) dan tekstur (Lawless dan Heymann, 1998).

\section{Analisa Data.}

Data yang diperoleh dari hasil perhitungan variabel dianalisa menggunakan analisis keragaman pola searah dengan menggunakan rancangan acak lengkap dan dilanjutkan dengan uji perbedaan rataan dengan menggunakan uji wilayah berganda Duncan (Steel dan Torrie, 1993). 


\section{HASIL DAN PEMBAHASAN}

Uji kualitas sifat fisik pada suatu bahan pangan merupakan indikator yang dapat menunjukkan tingkat penerimaan konsumen terhadap produk tersebut. Mutu kualitas sifat fisik daging entok yang direndam dalam cuka saguer yang diamati dalam penelitian ini, meliput $\mathrm{pH}$, daya ikat air dan tekstur. Hasil pengamatan pengaruh lama perendaman terhadap kualitas sifat fisik daging entok, selama penelitian disajikan pada Tabel 1 di bawah ini.

\section{pH}

Hasil pengamatan untuk perendaman daging entok dalam cuka saguer dapat dilihat pada tabel 1. Data rataan pengaruh lama perendaman terhadap $\mathrm{pH}$ daging berkisar antara 5,00 sampai 5,41. Rataan skor terendah berada pada perlakuan lama perendaman 80 menit yaitu 5,00 dan rataan tertinggi berada pada perlakuan kontrol yaitu 5,41. Data rataan hasil pengamatan menunjukan bahwa semakin lama daging entok direndam dengan cuka saguer maka $\mathrm{pH}$ daging semakin menurun.

Hasil analisis sidik ragam menunjukan bahwa perlakuan lama perendaman daging entok dalam cuka saguer berpengaruh sangat nyata $(\mathrm{P}<0,01)$ terhadap $\mathrm{pH}$ daging. Hasil Uji Wilayah Berganda Duncan menunjukan bahwa perendaman selama $20-80$ menit menggunakan cuka saguer dapat menyebabkan penurunan $\mathrm{pH}$ daging entok. Demikian pula terdapat perbedaan selama perendaman dengan menggunakan cuka saguer. Perendaman selama 20 - 40 menit meberikan pengaruh yang sama terhadap nilai $\mathrm{pH}$ daging entok, namun apa bila direndam terlalu lama sampai dengan 80 menit akan menurunkan nilai $\mathrm{pH}$ daging entok.

Tabel 1. Rataan Pengaruh Lama Perendaman Menggunakan Cuka Saguer Terdahap Peningkatan Kualitas Sifat Fisik Daging Entok.

\begin{tabular}{lccccc}
\hline \multirow{2}{*}{ Variabel } & \multicolumn{5}{c}{ Perlakuan (Lama perendaman) } \\
\cline { 2 - 6 } & R0 & R1 & R2 & R3 & R4 \\
& 0 Menit & 20 Menit & 40 menit & 60 menit & 80 menit \\
\hline $\mathrm{pH}$ & $5,41^{\mathrm{c}}$ & $5,25^{\mathrm{b}}$ & $5,24^{\mathrm{b}}$ & $5,14^{\mathrm{ab}}$ & $5,00^{\mathrm{a}}$ \\
\hline Daya mengikat air $(\%)$ & $22,11^{\mathrm{a}}$ & $25,90^{\mathrm{b}}$ & $26,53^{\mathrm{b}}$ & $26,56^{\mathrm{b}}$ & $26,64^{\mathrm{b}}$ \\
\hline${\text { Tekstur }\left(\mathrm{Kg} / \mathrm{cm}^{2}\right)^{\mathrm{ns}}}$ & 4.30 & 4.72 & 4.62 & 4.85 & 5.05 \\
\hline
\end{tabular}

Keterangan : superkrip berbeda pada baris yang sama artinya berbeda nyata $(P<0,05)$ 
Perbedaan nilai $\mathrm{pH}$ yang semakin menurun pada perendaman dengan cuka saguer, disebabkan karena kerja cuka saguer yang semakin lama. Penurunan $\mathrm{pH}$ yang bertahap yang relatif konstan dalam daging disebabkan oleh zat-zat buffer di dalam daging dan berperan dalam melepaskan dan menangkap ion $\mathrm{H}^{+}$dalam daging akibat kondisi asam.

Menurut Soeparno (2005) pH ultimat daging, yaitu $\mathrm{pH}$ yang tercapai setelah glikolisis otot habis atau glikolisis tidak lagi sensitif oleh serangan-serangan ensim glikolitik, normalnya adalah 5,4 5,8. Laju glikolisis post mortem pada daging menyebabkan terurainya glikogen menjadi glukosa, glukosa akan mengalami penguraian oleh enzim-enzim menjadi asam laktat (Candara-Dewi, 2012). Candra-Dewi (2006) menyatakan bahwa asam laktat daging sangat mempengaruhi nilai $\mathrm{pH}$ daging, dimana daging dengan asam laktat yang tinggi akan mempunyai $\mathrm{pH}$ daging yang rendah.

\section{Daya Mengikat Air}

Data rataan terhadap daya ikat air daging berkisar antara 22,11 sampai 26,64. Rataan skor terendah berada pada perlakuan R0 (0 menit) yaitu 22,11 dan rataan skor tertinggi berada pada perlakuan R5 yaitu 26,64
Hasil analisis sidik ragam menunjukan bahwa perlakuan lama perendaman dengan menggunakan cuka saguer berpengaruh sangat nyata $(\mathrm{P}<0,01)$. Dalam artian bahwa ketika daging entok direndam dengan cuka saguer selama 20 80 menit menyebabkan kenaikan daya ikat air dibandingkan dengan daging yang tidak direndam dengan larutan asam.

Hasil Uji wilayah Berganda Duncan pada setiap perlakuan menunjukan bahwa perendaman daging entok 20-80 tidak mengalami perubahan terhadap daya mengikat air. Walaupun uji Duncan menunjukan bahwa perendaman 20-80 menit tidak mengalami perubahan terhadap presentase daya mengikat air, namun kecenderungan data menggambarkan bahwa semakin lama direndam dengan larutan asam cuka saguer terjadi kenaikan presentase daya mengikat air. Kenaikan daya ikat air pada penelitian ini ada kaitannya dengan $\mathrm{pH}$ daging. Semakin asam kondisi daging yang direndam dengan cuka saguer diduga akan menurunkan keadaan lemak daging. Dengan demikian penurunan kandungan lemak suatu bahan dapat dipengaruhi oleh tingkat keasaman. Hidrolisa asam terhadap lemak pernah diteliti oleh Supirman et al. (2013) yakni perendaman dengan penambahan asam organik ekstra jeruk 
nipis terhadap kandungan lemak teh alga coklat, hasil penelitian menyatakan bahwa $\mathrm{pH}$ perendaman yang semakin asam menurunkan kandungan lemak teh alga coklat. Edwars (1981) menyatakan bahwa kadar lemak mempunyai kolerasi negatif dengan kadar protein. Penurunan lemak daging menyebabkan kenaikan jumlah protein daging (Purnamasari et al., 2013). Meningkatnya protein pada daging yang direndam dengan cuka saguer mengakibatkan daya ikat air meningkat. Linawati (2006) menyatakan bahwa daya ikat air dipengaruhi protein daging terutama protein miofibril dan sarkoplasma. Hasil penelitian Oktoviani (2002) yakni penambahan VCO dalam pakan broiler menyebabkan penurunan kandungan lemak daging dan meningkatnya protein daging sehingga terjadinya peningkatan daya mengikat air daging. Soeparno (2005) menyatakan bahwa daya daya mengikat air dipengaruhi oleh titik isoelektrik. Aberle (2005) menyatakan bahwa $\mathrm{pH}$ akhir daging mencapai titik isoelektrik $\mathrm{pH} 5,3-5,4$ jumlah gugus reaktif dari protein otot yang dimuati secara positif dan negatif sama. Apabila $\mathrm{pH}$ diatas titik isoelektik ataupun di bawah titik isoelektrik akan meningkatkan daya mengikat air. Pada penelitian ini, perendaman dengan cuka saguer yang mengandung asam asetat selama 20 - 60 menit menyebabkan $\mathrm{pH}$ daging turun di bawah titik isoelektrik. Hal ini disebabkan karena muatan $\mathrm{H}^{+}$lebih banyak sehingga menyebabkan daya mengikat air meningkat.

\section{Tekstur}

Tekstur daging merupakan bagian luar daging untuk mengetahui kasar dan halusnya daging yang ada kaitannya dengan keempukan. Menilai tekstur bahan pangan dapat diketahui dengan menggunakan indrawi atau nilai shear force daging. Nilai shear force daging menunjukan nilai keempukan daging tersebut alot dan bila nilainya rendah maka daging tersebut empuk.

Hasil pengamatan pengaruh perendaman daging entok dalam cuka saguer terhadap tekstur dapat dilihat pada Tabel 1. Rataan tekstur daging berkisar antara 4,30 - 5,05 $\mathrm{Kg} / \mathrm{Cm}^{2}$. Hasil analisis sidik ragam menunjukan bahwa perlakuan lama perendaman daging entok dalam cuka saguer tidak memberikan pengaruh yang berbeda nyata $(\mathrm{P}>0.05)$ terhadap tekstur daging. Artinya bahwa perendaman dengan cuka saguer selama 20 - 80 menit belum mampu merubah tekstur daging jika dibandingkan dengan tanpa perendaman dengan cuka saguer. Menurut Lawrie (1995), salah satu hal yang mempengaruhi tekstur daging adalah kandungan jaringan ikat serta ukuran berkas otot. Kusnadi et al. (2005) menyatakan tekstur daging 
banyak dipengaruhi oleh enzim kalpain yang merupakan proteolitik yang ada pada daging. Winarno (1997) menyatakan bahwa keaktifan ensim protease ditentukan oleh tingkat keasaman dari produk pangan.

Dilihat hari nilai $\mathrm{pH}$ hasil penelitian Tabel 1 menunjukan bahwa perendaman dengan cuka saguer menyebabkan penurunan nilai $\mathrm{pH}$. Diduga pH mempengaruhi aktivitas dari enzimenzim protease. Pada perendaman $20-80$ menit dengan cuka saguer belum menyebabkan perubahan tekstur daging. Kondisi enzim-enzim protease menyebabkan daya ikat serta sarkoplasmik pada daging tidak berubah.

Hoffman et al. (2003) melaporkan bahwa nilai $\mathrm{pH}$ daging mempunyai hubungan negatif dengam daya putus daging. Daging dengan nilai $\mathrm{pH}$ tinggi cenderung memiliki daya putus yang rendah. Bouton et al. (1971) menyatakan bahwa daging dengan $\mathrm{pH}$ tinggi lebih empuk dari daging dengan $\mathrm{pH}$ rendah.

\section{KESIMPULAN}

Perendaman selama 20 menit dengan cuka saguer dapat digunakan untuk merendam daging entok karena secara kualitas dapat mempertahankan tekstur daging dan meningkatkan daya ikat air daging pada kondisi $\mathrm{pH}$ daging yang normal.

\section{DAFTAR PUSTAKA}

Aberle, E.D., C.J. Forest, H.B. Hedrick, M. D. Judge dan R.A. Merkel. 2001. The Principle of Meat Science. W.H. Freeman and Co. San Fransisco

Bouton, P.E. and P.V. Harris. 1972. The effect of cooking temperature and time on some mechanical properties of meat. J. Food. Sci. 97:140-144.

Candra-Dewi, S.H. 2006. Pengaruh Pemberian Gula, Insulin dan Lama Istirahat sebelum Pemotongan pada Domba setelah Pengangkutan terhadap Kualitas Kimia Daging. Prosiding Seminar Nasional, UNDIP Semarang.

Chandra-Dewi, S.H. 2012. Populasi mikroba dan sifat fisik daging sapi beku Selama penyimpanan. Jurnal AgriSains Vol.3 (4): 1-12

Djarijah, A.S. 2002. Teknologi Tepat Guna Usaha Ternak Itik. Kanisius. Yogyakarta

Edwards, H.M. Jr. 1981. Carcass composition studies. 3. Influence of age, sex and calorie protein contents of the diet on carcass composition of Japanese quail. Poultry Sci. 60: 2506-2512. 
Hoffman, L.C., M. Muller, S.W.P. Cloete, and D. Schmidt. 2003. Comparison of six crossbred lamb types: sensory, physical and nutritional meat quality characteristics. Meat Sci. 65: 1265-1274.

Kusnadi, D.C., V.P. Bintoro, dan A.N. AlBaarri. 2012. Daya ikat, tingkat kekenyalan dan kadar air protein pada bakso kombinasi daging sapi dan daging kelinci. Jurnal Aplikasi Teknologi Pangan 1:2

Lawless, H. T. And H.Heyman. 1998. Sensory Evaluation of Food. Chapman \& Hall Publisher. New York, USA.

Lawrie, R.A., 1995. Ilmu Daging. Diterjemakan oleh: A. Parakkasi. UI-Press, Jakarta

Linawati. 2006. Kadar Protein kolagen dan hubungan dengan kualitas daging sapi PO. Laporan Penelitian. Universitas Gadjah Mada. Yogyakarta

Nurwantoro, V.P. Bintoro, A.M. Legowo, A. Purnomoadi, L.D. Ambara, A. Prakoso, S. Mulyani. 2012. Nilai $\mathrm{pH}$, kadar air, dan total escherichia coli daging sapi yang dimarinasi dalam jus bawang putih. J Aplikasi Teknologi Pangan. 1:20-22.

Oktaviana, D. 2009. Pengaruh pemberian ampas virgin coconut oil dalam ransum terhadap performan, produksi karkas, perlemakan, antibodi, dan mikroskopik otot serta organ pencernaan ayam broiler. Tesis. Fakultas Peternakan UGM, Yogyakarta.

Purnamasari, E., Mardiana, Y. Fazila, W.H.Z. Nurwidada, D. Febrina. 2013. Sifat fisik dan kimia daging sapi yang dimarinasi jus buah pinang (Areca catechu L.). Prosidding. Seminar Nasional Teknologi Peternakan dan Veteriner. 216-226

Soeparno, 2005. Ilmu dan Teknologi Daging. Cetakan Keempat. UGM Press. Yogyakarta.

Supirman, Hartati Kartikaningsih, Kartini Zaelani. 2013. Pengaruh perbedaan $\mathrm{pH}$ perendaman asam jeruk nipis (Citrus auratifolia) dengan pengeringan sinar matahari terhadap kualitas kimia the alga coklat (Sargassum fillipendula). THPi Student Journal Vol 1(1): 4652

Steel, R. G. D. dan J. H. Torrie. 1993. Prinsip dan Prosedur Statistika, Suatu Pendekatan Biometrik. Alih bahasa B. Sumantri. PT Gramedia Pustaka Utama. Jakarta.

Winarno, F. G. 1997. Kimia Pangan dan Gizi. PT Gramedia Pustaka Utama. Jakarta. 